\title{
LATAR BELAKANG PENYEBAB TAWURAN PADA REMAJA
}

\author{
BACKGROUND CAUSES OF CLAIM IN ADOLESCENT
}

\author{
Diana Imawati \\ Fakultas Psikologi, Universitas 17 Agustus 1945 Samarinda \\ Email: diana_ima@yahoo.co.id
}

\begin{abstract}
Abstrak: Tujuan peneliti ini adalah ingin mengetahui penyebab mengapa remaja suka melakukan tawuran. Hasil dari penelitian adalah (1). Terdapat remaja atau anak-anak muda Kayutangi dalam pengelompokan atau gank dan mereka mudah terpancing emosi, (2) . Remaja membawa pisau dan sejenisnya. Ketika polisi tahu mereka pergi ke lokasi yang bersangkutan untuk mengamankan situasi dengan menangkap mereka. Saran-sarannya adalah (1). Untuk menganjurkan keamanan lokal untuk dijaga, (2). Orangtua harus membimbing anak-anak mereka dengan baik dengan memberikan perhatian, nasehat, kontrol, mendampingi dan mencintai mereka, (3). Polisi membuat peta lokasi, (4). Sekolah mengajarkan sikap yang baik (5).Pemerintah membawa keluar kegiatan positif untuk remaja.

Kata kunci: pertarungan, panduan, orang tua, polisi, remaja

Abstract: The aim of the researcher is willing to know the causes why the teneegers like weto fight each other. The results of the research are (1).There were youngsters Kayutangi in grouping and they were angry as they were ready to fight, (2). They brought knives and the like. As the police knew it they went to the location concerned to make the situation secured by catching them .The suggestions are (1).To encocourage the local security to guard,(2).The parents have to guide their children well by giving advice, control, accompany and love them,(3).The police makes a map of the location,(4).The school teaches the good attitude (5).The government carries aout the positive activity for teneegers
\end{abstract}

Keywords: fight, guide, parents, police, teneeger 


\section{PENDAHULUAN}

Masa remaja juga disebutkan sebagai masa badai dan stress (storm and stress) yaitu suatu masa di mana ketegangan emosi meninggi sebagai akibat dari perubahan fisik dan kelenjar. Meningginya emosi disebabkan karena remaja berada dalam sebuah tekanan yang menuntutnya untuk menjadi harapan baru yang baik di masa depan. Keadaan tertekan semacam ini juga dapat menyebabkan gagalnya seorang remaja menyelesaikan sebuah permasalahannya, sehingga masa remaja sering dikatakan sebagai usia bermasalah. Masalah-masalah yang terjadi pada remaja sering menjadi masalah yang sulit untuk diatasi juga dikarenakan para remaja merasa mandiri, sehingga mereka ingin mengatasi masalahnya sendiri dan menolak bantuan keluarga, orangtua dan guru. Selain itu, remaja juga dituntut untuk bertanggung jawab terhadap pengendalian perilaku sosialnya sendiri, sesuai dengan harapan sosial (Hurlock, 1999).

Banyak faktor yang dapat menyebabkan terjadinya kenakalan yang dilakukan oleh remaja, misalnya tumbuh dalam keluarga yang berantakan, kemiskinan dan lain sebagainya. Tingginya keterlibatan remaja dalam tawuran memberikan penekanan pada mitos yang selama ini diakui masyarakat bahwa masa remaja adalah periode labil. G. Stanley Hall (1904, dalam Lilienfield, 2012:38) menyebutkan bahwa masa remaja sebagai masa "penuh badai dan stres". Hal ini ditekankan pula oleh Anna Freud (1958, dalam Lilienfield, 2012:38) yang berpendapat bahwa pergolakan emosional ketika remaja merupakan hal yang lazim. Elkind (dalam Papalia, Old \& Feldman, 2008:561-562) menjelaskan bagaimana remaja tumbuh dengan pemikiran yang belum matang sehingga memiliki idealisme, tendensi untuk unjuk kemampuan, ragu-ragu, plinplan, cara pandang egosentris dan merasa khusus.

Dalam syair lagu Koes Plus bahwa masa remaja masa yang paling indah. Di sini artinya luas yaitu bermakna bebas, tidak ada tanggungjawab, berkreasi, berbahagia, bersendagurau melulu dan suasana diatur sendiri. Tetapi itu jaman dulu tetapi saat ini tidak bisa demikian karena mereka harus sekolah, belajar, mengerjakan tugas, pekerjaan rumah, jadwal les privat, membantu orang-tua dan kegiatan sosial kemasyarakatan.

Seseorang yang memiliki semangat bagus, sikap dan perilakunya biasanya terlihat dinamis. Semangat itu memiliki fungsi sebagai penggerak batin untuk bertidak. Semangat itu sifatnya spiritual, adalah dimana batin tergerak untuk bertindak. Semangat juga bersifat anginanginan, dia terkadang ada dan tidak ada. Semangat tidak hanya datang satu kali, bisa puluhan kali atau ratusan kali bahkan lebih. Semangat bisa datang dan pergi berulang kali tanpa bisa dihitung. Semangat yang melemah bisa ditambah dengan beberapa hal dibawah ini, diantaranya adalah :

- Merasa HARUS bertindak

- Keinginan untuk melakukan sesuatu yang bermakna bagi diri sendiri, keluarga, kerabat dan orang banyak serta alam semesta

- Perasaan bertanggung jawab

- Merasa peduli terhadap sesama, dan lain-lain

Diperlukan tekad yang kuat untuk mempertahankan semangat. Jika sekarang anda merasa sedang memiliki semangat, anda pula seharusnya mengingat-ingat satu kondisi dan situasi dimana semangat itu sedang pergi atau dengan kata lain ketika anda sedang tidak bersemangat, maksudnya adalah agar anda bisa merasakan apa saja perbedaannya, lalu mempertahankan eksistensinya atau bahkan untuk menambah kekuatan dari semangat itu. Berikut penjelasannya :

1. Jiwa muda itu energik yaitu, emosional , solider dan bergerak cepat;

2. Jiwa muda itu energik yaitu lincah, penuh kreasi dan invasi serta banyak aktivitas;

3. Jiwa muda itu emosional yaitu jiwanya cepat tanggap yang biasanya kurang bijaksana;

4. Jiwa muda itu solider yaitu jiwa setia kawan sangat kuat sehingga ia tidak segan-segan membelanya walaupun salah;

5. Jiwa muda itu bergerak cepat yaitu tidak sabar menunggu sehingga pekerjaan 
segera selesai walau kadang-kadang
meleset.

\section{METODE PENELITIAN}

Metode Observasi Observasi adalah suatu cara pengumpulan data dengan pengamatan langsung dan pencatatan secara sistematis terhadap obyek yang akan diteliti. Observasi dilakukan dengan metode observasi non partisipan. Peneliti melakukan pengamatan dan pencatatan serta mengumpulkan informasi dari berbagai sumber yang memperkuat penelitian.

\section{HASIL DAN PEMBAHASAN}

\section{Kasus Tawuran Remaja}

Salah satu contoh tawuran di Banjarmasin yaitu sebuah berita tawuran antar remaja dari Banjarmasin Post dengan judul, "Bawa Celurit Mau Tawuran, Puluhan Anak Punk Langsung Kocar-kacir Lihat Polisi." $\begin{array}{llll}\text { (Minggu, } 9 & 9 & \text { April } & 2017 \\ \text { 15:42 }\end{array}$ banjarmasinpost.co.id/fadly setiarahman). Polisi amankan sejumlah anak punk dan sita senjata tajam yang akan digunakan tawuran. Kemudian berita dari Tribun Kalimantan Timur.co - Puluhan anak punk lari kocak-kacir ketika aparat kepolisian datang ke lokasi yang nyaris saja akan dijadikan tempat tawuran, Sabtu (8/4/2017) malam.

Anak punk yang sebelumnya nyaris saling serang di kawasan Jalan Pangeran, Banjarmasin Utara, Banjarmasin, Kalimantan Selatan, langsung mencoba kabur dari sergapan aparat Buser Polsekta Banjarmasin Utara dan Satreskrim Polresta Banjarmasin. Kebanyakan mereka memilih kabur ke gang sepi di dekat Jembatan Pangeran Banjarmasin. Kata seorang warga, Rahman, bahwa ada yang kabur ke kawasan Sungai Miai, Antasan, Kayutangi lalu juga ke Jalan Pangeran arah Kuin. Anak-anak itu kabur dengan melintasi gang-gang sepi. Beberapa warga juga sempat menyaksikan ada beberapa anak yang diamankan pihak kepolisian. Lanjutnya bahwa ada tadi yang diamankan polisi. Katanya anak-anak itu mau tawuran, mereka juga membawa senjata tajam, sahut salah seorang warga Jalan Pangeran. Sebelumnya, nyaris pecah tawuran anak punk di kawasan Jalan Pangeran Antasari Kecamatan Banjarmasin Utara, Sabtu (8/4/2017). Beruntung aparat kepolisian langsung gerak cepat ke lapangan begitu merebak kabar tawuran anak punk di kawasan itu.

Sebelumnya didapat informasi bahwa ada sekumpulan anak-anak yang membawa senjata tajam berkeliaran di kawasan dekat Jembatan Pangeran Antasari Banjarmasin dan mengamankan mereka.

\section{Pendidikan Karakter yang Sehat Mental}

Dalam Undang-Undang No. 20 Tahun 2003 tentang Sistem Pendidikan Nasional, pendidikan nasional seharusnya merupakan pengembangan kemampuan dan membentuk watak serta peradaban bangsa yang bermartabat dalam rangka mencerdaskan kehidupan bangsa. Selain itu juga bertujuan untuk mengembangkan potensi peserta didik agar menjadi manusia yang beriman dan bertakwa kepada Tuhan Yang Maha Esa, berakhlak mulia, sehat, berilmu, cakap, kreatif, mandiri, dan menjadi warga negara yang demokratis serta bertanggung jawab. Aspek yang disebutkan di atas diturunkan dalam 18 nilai-nilai karakter, yaitu religius, jujur, toleransi, disiplin, kerja keras, kreatif, mandiri, demokratis, rasa ingin tahu, semangat kebangsaan, cinta tanah air, menghargai prestasi, bersahabat dan komunikatif, cinta damai, gemar membaca, peduli lingkungan, peduli sosial, dan tanggung jawab. Psikolog E. Singgih (2011) menyimpulkan bahwa nilai tersebut hanya dapat dibentuk melalui pendidikan karakter. Sayangnya, pendidikan tersebut tidak bisa terjadi tanpa adanya dinamika 3 komponen, yaitu mengetahui, merasakan dan melakukan. Pendidikan karakter membantu siswa untuk mengembangkan Adversity Intelligence, yaitu kecerdasan yang membuat seseorang mampu bertahan melewati situasi sulit, dengan kata lain kemampuan bertahan terhadap stres (tekanan). Implikasinya jelas, bahwa pendidikan moral tidak cukup dengan mendiktekan norma sosial di depan kelas, anak didik juga perlu diberikan keterampilan untuk melakukannya. Lebih jauh lagi, mereka perlu 
ditumbuhkan kemampuan untuk bangkit ketika terjadi permasalahan sehingga tidak menjadi manusia rapuh yang mudah melampiaskan agresi ketika tidak mampu mengontrol emosinya.

WHO menetapkan indikator kesehatan mental positif di level individu yang disandarkan pada adanya koneksi sosial, kesadaran diri, dan penghargaan pribadi yang kuat. Indikator ini dapat melibatkan ukuran rasa memiliki, selfesteem (harga diri), keterikatan, keinginan diri dan kontrol serta kualitas hidup (Vichealth, 1999; Zubrick dll, 2000b, dalam WHO, 2005:160). Indikator keluarga dapat meliputi kesehatan mental orang tua, bebas dari kekerasan, kedekatan keluarga, keterikatan orang tua dan anak, serta praktik orang tua yang responsif, tepat seperti memonitor aktivitas anak dan memastikan lingkungan yang aman bagi mereka.

Namun, pada kenyataannya, pendidikan di Indonesia hanya berfokus pada sisi materi demi memperoleh nilai tertinggi, dengan melupakan pendidikan karakter. Dampaknya membahayakan bagi anak didik yang tidak memiliki kemampuan untuk bertahan terhadap tekanan. Tidak heran jika jumlah tawuran semakin lama semakin meningkat karena tawuran dijadikan media untuk melampiaskan tekanan akademis tersebut. Para psikolog setuju perlunya pengembangan pendidikan karakter yang mampu memberikan pedoman bagi generasi muda mengenai norma sosial yang patut. Sejalan dengan itu, dirasa perlu untuk mempersiapkan peraturan perundang-undangan yang bertujuan menjaga kesehatan mental generasi muda.

Terkait dengan pengaturan di atas, maka perlu didorong pengaturan mengenai usaha promotif dan preventif kesehatan mental di dunia pendidikan. Dengan begitu, sekolah menjadi pos penting dalam menjaga dan mengajarkan kemampuan untuk mengontrol diri bagi generasi muda. Pentingnya melibatkan dunia pendidikan didasari oleh besarnya pengaruh sekolah terhadap kehidupan seseorang. Rata-rata seperempat kehidupan manusia dihabiskan di bangku sekolah dengan asumsi setiap orang dapat sekolah hingga perguruan tinggi. Sekolah juga merupakan institusi kedua setelah keluarga yang mengajarkan keterampilan-keterampilan awal pada manusia, termasuk pengetahuan moral. Diharapkan dengan adanya peran sekolah dapat membekali remaja untuk mampu bertahan di tengah permasalahan hidup yang dihadapi dan tidak mudah mencari pelampiasan yang merugikan.

Hasil penelitian tentang sebabmusabab tawuran terkait dengan remaja adalah bahwa mereka : (1). Kelebihan energi, (2). Emosi sulit dikontrol, (3). Asal keluarga yang broken home, (4). Pergaulan yang salah, (5). Melihat perilaku di Media sosial, (6). Menyaksikan tayangan di televisi, (7). Kurang diawasi oleh orang-tua karena sibuk karir sebagai pejabat atau pengusaha, (8). Keluarga yang kurang mampu, (9). Mencari jati diri dan pengakuan pihak lain sebagai pemberani, (10). Pemerintah kurang memberi apresiasi, beasiswa, tempat rekreasi, olah-raga, menyalurkan hobi dan menyapa mereka, (11). Kurang adanya suri tauladan dari para tokoh masyarakat atau pejabat pejabat misalnya masih ada perilaku Kolusi, Korupsi dan Nepotisme, (12). Kurang lapangan kerja, (13). Lambatnya regerasi pimpinan , (14). Adanya diskriminasi di semua lapisan.

\section{KESIMPULAN}

Kesimpulan dari penelitian ini adalah : (1). Bahwa di sekitar wilayah Kayutangi terjadi sekumpulan anak-anak muda (punk) bergerombol, (2). Mereka bringas, (3). Mereka bersiap untuk tawuran, (4). Untunglah begitu Polisi mengetahui dan dengan gerak cepat ke lapangan, (5). Polisi mengamankan mereka, (6). Yang tidak tertangkap melarikan diri ke ganggang sepi sekitar Kayutangi, (7). Sebagian besar dari mereka adalah remaja (punk).

\section{DAFTAR PUSTAKA}

Calon dalam Monks, dkk 1994,Makalah Psikologia ,Jakarta ; 
Hanna Djumhana Bastaman, 1997, Integrasi Psikologi Dengan Islam; Menuju Psikologi Islami, Pustaka Pelajar, Jogjakarta.

Hurlock, 1992 , Makalah Psikologi, Jakarta.

Kompasiana, 26 April 2013

Lilienfield, Scott O, dkk. 2012. 50 Mitos Keliru Dalam Psikologi. Yogyakarta: B.First.

Papalia, Diane E., Old, Sally Wendkos, \& Feldman, Ruth Duskin. 2008. Human Development (Psikologi Perkembangan, Edisi kesembilan). Jakarta: Prenada Media Grup.
Sarlito Wirawan Sarwono, 1986 , Berkenalan Dengan Aliran-Aliran Dan Tokoh-Tokoh Psikologi, Bulan Bintang , Jakarta.

Santrock, 2003 , Makalah Psikologi Jakarta.

Sri Rumini \& Siti Sundari 2004,Makalah Psikologi, Jakarta.

Surat Kabar Harian , Banjarmasin Post, Sabtu 8/4/2017, Banjarmasin.

World Health Organization. 2005. PromotingMental Health: Concept, Emerging Evidence, Practice.Switzerland: WHO Press.

Zakiah Darajat ,1990 ,Makalah Psikologi , Jakarta. 